\title{
GREAT POWER RIVALRY AND MILITARY ACTIVITIES IN THE SOUTH CHINA SEA
}

\author{
K S Balakrishnan \\ Department of International and Strategic Studies \\ Faculty of Arts and Social Sciences \\ University of Malaya \\ Kuala Lumpur. Malaysia \\ (ksbalakrishnan@um.edu.my) \\ DOI: https://doi.org/10.22452/samudera.vol1no1.2
}

\begin{abstract}
The South China Sea has become the new battleground for military rivalry with the end of the Cold War between superpowers. The introduction of UNCLOS in 1982 has only worsened the issue of maritime disputes as many claimant states engage in all kind of military activities in order to strengthen their respective national maritime claims. The United States and China tend to also raise different perspectives on the dispute. Efforts are being taken to upgrade the maritime military capabilities both from the naval and air power dimensions. The US has aided the Philippines in small ways, and Washington has its strong view on the freedom of navigation while it is not a claimant. Military activities and presence in this zone can also be viewed from a geopolitical perspective. There are also the interests of the other external players who regard the safety of navigation in these waters as vital to the interests of all, and not just to the contesting states. China's military rise is also a major concern for all for, both large and small nations. This article will provide an overarching view of the military dynamics and geopolitics in the South China Sea.
\end{abstract}

Keywords: South China Sea, military activities, rivalry, United States, China

\section{Introduction}

The South China Sea has changed significantly as a zone of conflict and rivalry, with a new twist with the end of the Cold War. The attempt to control the maritime space of the South China Sea reminds us in many ways that a new Cold War is already on the trajectory given the worsening US-China relations during the Trump era. The US has begun to take its position in Danang, once a base for the USSR military during the Cold War, to curb China and the US. The US-China bilateral ties were also not all that solid under the Obama administration. With Trump, it is getting worse, and tensions are high because of trade issues. The US military too is not happy with the way in which China treats its interest in the disputed territorial areas of the maritime space in East Asia as a whole. China's relationship with Japan, Vietnam, Philippines and the US is worsening on the maritime battlespace. This is also influenced by the US who for the first time to 
clearly articulate that the South China Sea is a part of its "national interest." What that means is quite ambiguous and open to interpretation. But the intensity of US presence in the South China Sea has definitely on the increase during the Obama era and now under the Trump administration through FONOPs (freedom of navigation operations).

The South China Sea is commonly known as a semi-enclosed sea. It is a strategic body of water linking the Straits of Malacca to East Asia, which is historically and in a contemporary sense, remains a vital sea lane. It is connected with the Far East via the Taiwanese waters and the East China Sea, Yellow Sea and the Sea of Japan. It is the natural waterway for one of the most economically dynamic regions of the world involving countries like China, Taiwan, South Korea and Japan. Hong Kong is another important economic entity that forms as a vital port. Cambodia, Vietnam, Thailand, Malaysia, Brunei, Indonesia and the Philippines have become important economic entities of the ASEAN countries engulfed by the South China Sea, the Gulf of Thailand and the Gulf of Tonkin. From the United Nations Convention on the Law of Sea (UNCLOS) point of view, the South China Sea also borders two major archipelagic states, namely Indonesia and the Philippines. Military interests and rivalry of the players surrounding this strategic body of water are numerous. They range from the context of geo-politics, geo-strategy and, for the contesting claimants, it is about sovereignty and their immediate military control of the disputed areas and threat perception.

This article will specifically deal with the recent rivalry between the US and China in ensuring that the South China Sea and its surrounding maritime space remains girded within their strategic interest for long-term survival. It will outline both the US and China's respective maritime strategies and activities in order to take control of this area not only from a sea line of communications (SLOCs) point of view but also behind the backdrop of geopolitics and geo-strategy in a post-Cold War era. The interests of other claimants, military developments and prospects for conflict resolution are also covered briefly.

\section{The US Strategic Interests in the South China Sea: From Obama to Trump.}

As a strategic body of water that is vital for the superpowers, the great power which can control the sea lanes will have the upper hand in power rivalry. The US had its bases in Clark, Subic Bay and other facilities in the Philippines during the Cold War. The USSR was using Danang and Cam Ranh Bay in Vietnam for its military activities in order to balance one another's influence in the region. With the end of the Cold War and the collapse of the USSR, these foreign military bases disappeared. The US currently maintains military facilities in Singapore under a visiting forces agreement signed in the early 1990s. After the withdrawal from the bases in the Philippines, another facility and visiting forces arrangement were made after September 11, 2001. While the superpower confrontation ended in Southeast Asia, the US has yet to withdraw from Southeast Asia fully militarily. It remains engaged in numerous bilateral alliances and military exercises in Asia. The US-Japan, US-Korea, US-Taiwan and US-Australia, USPhilippines are important agreements and alliances that are regarded as helpful to the stability and security of the Asia Pacific region. Several ASEAN countries such as the Philippines, Thailand, Vietnam, Singapore, Malaysia and Indonesia are receiving 
assistance from the US and conduct low-level military exercises with the US. Some military exercises are regular, and others have been occasional.

Since September 11, 2001, the US engagement in the South China Sea region has increased manifold. New forms of security cooperation have been established involving initiatives such as the RMSI (Regional Maritime Security Initiative), PSI (Proliferation Security Initiative), CSI (Container Security Initiative) and ISPS (IMO's International Ship and Port Security Facility Code) (Shie, 2004). The presence of the US is generally perceived as a stabilizing factor by the ASEAN countries, although occasionally some of them complain over Washington's military dominance. While the role of the U.S. in Southeast Asia is seen as a militarily stabilizing factor, it is not the case when the U.S. attack on Iraq and Afghanistan is concerned. Both Indonesia and Malaysia, which are Muslim nations, have not supported the US invasion of the two Muslim nations after 9/11.

Maritime cooperation in the suppression of maritime terrorism, naval exercises for search and rescue and disaster relief are important areas being used by the U.S. to establish a constant presence in the waters of the Indian Ocean, the Straits of Malacca and the South China Sea. The US military's intelligence-gathering activities in the South China Sea have yet to recede despite the end of the Cold War. The sea is viewed by the contesting claimants as a vital strategic point for military interdiction and intelligence gathering activities, not to mention as a zone of military confrontation. Non-military issues like piracy and environmental security are also major concerns. Tension in the South China Sea has increased after the 9/11 as external players are also getting involved due to the concern over the safety of navigation in the Straits of Malacca bordering the South China Sea. These external powers who are interested in the new strategic developments and have an impact either directly or indirectly, include the US, India, Australia, and Japan. While terrorism, piracy, sea lanes and safety of navigation are of major concern, the fear of China's military rise and activities in the South China Sea bother these external players who are not a party to the territorial disputes in the Spratlys or the Paracel group of islands.

China's military does not welcome the US' role in the South China Sea. China views US intelligence-gathering activities in the South China Sea as provocative, such as the 2000 spy plane incident on Hainan Island. While the issue was peacefully resolved, the tension in US-China bilateral relations increased in that year resulting from numerous cyberattacks on US military and commercial websites. Recent years have witnessed the rise of intelligence-gathering activities in the maritime zone. This will be of concern for Malaysia and other nations in protecting their national interests. The stand-off between the US surveillance vessel, the Impeccable, conducting intelligence activities in the South China Sea and five Chinese vessels in March 2009 is an important significant event. The above two incidents of spying has triggered China to upgrade its naval regiment near Hainan. Since then, China has also increased military manoeuvres near Hainan Island and the whole of the South China Sea.

All do not welcome the conduct of surveillance by US ships in the South China Sea. Only a few ASEAN states view the US forces as an important stabilizer. Singapore was already offering alternative plans for naval facilities for the US during the initial plan of withdrawing from the Philippines (Far Eastern Economic Review, 1990). Singapore looked at it as nothing new but purely the bolstering of the existing security 
facility agreement with the US forces. ASEAN countries also did not make much noise on Singapore's move to host more of the US visiting forces because the arrangement was no longer like the bases hosted by the Philippines during the Cold War. On the contrary, China's navy had attempted to prevent such activities by the US and others. China's ambition to become a major naval power is unavoidable, given the challenges it faces. Similarly, concerns over the potential for maritime terrorism in the Straits of Malacca affect stakeholders from the Middle East, East Asia and the Pacific. The US feels that the maritime space must be kept free, and no one should exercise dominance on vital sea lanes. In sum, military development, rivalry and the potential for increased tension is inevitable. The rise in technology and supplied side pressure are other dimensions to be considered in the military build-up in the region that warrants attention.

The US position and policy on the South China Sea is indeed ambivalent. On the one hand, the US believes that the contesting claimants should resolve their dispute peacefully and prefer not to get involved in sovereignty disputes. On the other, the US military is involved in intelligence gathering activities that are, from China's point of view, provocative. Mark Valencia, an expert on maritime security, points out that military and intelligence-gathering activities in the Exclusive Economic Zone (EEZ) areas are likely to increase. This will also push nations to procure more ships and military arsenal systems to protect their EEZs from encroachment. He also argues that there are loopholes in the 1982 UNCLOS which will create problems. For example, in his view "the US and other maritime powers may argue that military intelligence gathering activities and hydrographic surveys are distinct from marine scientific research," and are not covered well by UNCLOS (Valencia, 2004).

For many years, the US has refused to ratify the 1982 UNCLOS for several reasons. This includes its position on the issue of the navigational rights of ships to critical seaways and the challenges coming from states who attempt to restrict 'innocent passage' rights stipulated by this international treaty (King Jr, 2007). Although the US has been positive lately on UNCLOS, it is important to understand the US strategy and position in its proper historical context. During the UNCLOS sessions in 1982 in Montego Bay, the US and the Soviet Union were against the potential interpretation on the territorial sea and the issue of states requesting prior notification of the innocent passage of warship. India and the US have established strong security linkages in the wake of the post-9/11 era.

Similarly, the US was concerned over the control of littoral states over international straits (Bergin, 1983). The US did not support the UNCLOS regime due to its strategic naval interests in an era of intense nuclear and conventional arms rivalry with the Soviet Union. The US was also opposed to claims of 200 nautical miles EEZs by littoral states in important sea areas which would naturally affect its interest. India and the US have established strong security linkages in the wake of the post-9/11 era.

Besides the above US concerns, it is also important to take cognizance of the commercial interests of American companies which conduct business with the littoral states of the South China Sea. US oil companies are also engaged with both Vietnam and China, two of the major claimant states in the Spratlys, for concessions on oil explorations in the disputed EEZs of the northern part of the South China Sea and near the Gulf of Tonkin. How much the US takes into account the commercial interest factor 
in their military intelligence gathering activities is not clear. However, it is difficult to underestimate the fact that the foreign policy of pursuing commercial interests and its linkage to military-strategic interests goes hand in hand in most instances.

During the early years after the Cold War, the US was quite clear with its position on the South China Sea. It played a very much benevolent role. In 1992, then US Senator William Cohen stated that the US would not take sides on issues pertaining to territorial disputes of the Spratlys but was happy to play a mediator role if given a chance (Talib, 1992). Admiral Charles Larson, the Commander of the Pacific Forces also stated in April 1993, that the dispatch of China's submarines in the Spratlys was not seen as a threat (NST, 2010a). At the time, the US did not regard China as a threat in the South China Sea. In fact, the US was supporting Indonesia initiated South China Sea Dialogues. China's adventure into the Mischief Reef located within the Philippine EEZ became a problem when Manila invoked the US-Philippine Mutual Defence Treaty. Although the US was not happy about the situation, it did not come up with an aggressive statement and requested the disputing parties to use the ASEAN 1992 Declaration on South China Sea principles as a way to resolve issues by peaceful means. While the US did not guarantee the Philippines that it would interfere, it provided training and conducted military exercises in that vicinity. The US' position was concerned with access to freedom of navigation and took the occasion to remind claimants not to go beyond UNCLOS in interpreting sovereignty issues (Valencia, 1995). Throughout the 1990s, the US never officially took sides on the issue of the Spratlys and Paracels territorial disputes in the South China Sea.

Today the scenario is different as the fear over China's growing military strength is a concern for all. The US tends to be more vigilant on China's military rise. The challenge posed by China's vessel on a US ship in April 2009 is a reminder to the US that it is facing new security challenges in the South China Sea while having the opportunity to conduct the military exercise with Vietnam. The US has, in recent years, been putting some pressure on China by internationalizing security issues of the South China Sea in a regional security forum like the ASEAN Regional Forum (ARF). In July 2010, Secretary Hillary Clinton raised this issue at ARF by stating that the US is concerned that the territorial disputes of the Spratlys and Paracels can affect maritime commerce and hamper access to sea lanes or international waters. The US was also worried that this dispute could undermine the freedom of passage stipulated by UNCLOS, which is a major concern for US national interest. China was not in favour of the US, bringing up the issue of the South China Sea at ARF. Beijing prefers this issue to be discussed only by the disputing states, preferably in a bilateral forum. The US approach and calls for multilateralisation of the issue is not welcomed by all. Both China and other claimants prefer the issue not to be highlighted due to increasing tension, and would rather find a diplomatic solution. A reference to military exercise restraint in line with the ASEAN Declaration on the Code of Conduct of Parties has also been mention by some parties (Hassan, 2010; NST, 2010b). While one or two ASEAN states may give support to the US proposal and welcome its role, some would prefer not to "rock the boat." China is also upset with Vietnam's attempts to secure US naval support and had warned that it would be counterproductive.

Apart from Secretary Hilary Clinton's remarks on the possible role that the US could play in the South China Sea dispute, Washington views the area as a part of its 
'national interest'. US Secretary of Defence, Robert Gates also attended the Shangri-La Dialogue in August 2010 in Singapore and stated that the US viewed the South China Sea as a part of its national interest, especially where freedom of navigation is concerned. He stated that it is not in the interest of the US to side with any party on the issue of their respective sovereignty claims (Bateman, 2010). Sam Bateman, a leading Australian maritime analyst, believes that the reason for the US assertion on freedom of navigation has got to do with two important events or developments. The first was the March 2009 incident where China's vessels harassed the USNS Impeccable, the ocean surveillance vessel, near Hainan that was conducting scientific research. The second incident was Malaysia and Vietnam's joint submission to the United Nations Commission on the Limits of the Continental Shelf (UNCLCS) claiming the outer limits of the continental shelf and the resources therein (Bateman, 2010).

While this analysis may be true, it is important to examine the US global maritime strategy as a whole, which actually serves the US naval defence and strategy both during the Cold War and in the aftermath of the era. During the era of détente in the 1970s until the late 1980s, the US was more silent on the issue of the South China Sea. It was important to ensure that China remained a challenge to the USSR, instead of becoming a serious enemy of the US. China too had its own worries of the USSR's presence in Cam Ranh Bay and Danang, notably when the USSR attacked the Paracels Island and took it forcefully from Vietnam. Similarly, when China attacked Vietnam near the Spratlys in 1988, the US and USSR were both silents. The US was a neutral player because of its fear of USSR and needed China as a counter-balance after the famous détente with PRC following Nixon's visit in 1972.

With the end of the Cold War and the emergence of the PRC's armed forces as a significant challenge in regional waters in the South and the East China Sea, the US position has significantly changed. Washington has continuously been vigilant of China's military rise. It has been observing the way China has developed its navy and the added maritime dimension in the South and the East China Sea. The 1995 Mischief Reef incidents, the Spy Plane incident in 2000 near Hainan and the USNS Impeccable incident in 2009 have all served as vital warnings to assert the US position on freedom of navigation and to protect the US and that of its allies.

The US has upgraded the Japan-US Alliance agreement to focus on China as the potential enemy. It has sent an aircraft carrier near Taiwan in the wake of the PRC's missile test in 1996. It has also brought Mongolia into the alliance system and has engaged Russia positively in NATO and the alliance's expansion towards Eastern Europe and Central Asia. Both China and Russia were concerned with the support of some Western and East Asian allies that are economically powerful as well. Not only have South Korea and Japan remained as the US' strongest allies, but the US has also been cultivating its ties with India in the India Ocean and with Vietnam in the South China Sea. Cultivating stronger US-India security cooperation was crucial to curb China's influence in the Indian Ocean via countries like Myanmar, Bangladesh, Pakistan and Iran. The cultivation of a military relationship with Vietnam and Thailand in the South China Sea is sufficient to conduct surveillance, military intelligence activities and access. Malaysia too has been warming relations with the US on military exercises. 
Therefore, it is important to point out that the recent US assertion of its national interests in the South China Sea is not something new but has been part of the long term calculated strategy to check China and other navies' reach in vital or strategic sea lanes. Although it is not in the US interest to wage war with China, it is important to ensure such long term dominance in the region. The Obama Administration's recent interest to improve its relationship with ASEAN is also planned in this direction after long neglect on the part of the US in dealing with Southeast Asia and the worry that ASEAN may fall into China's "lake." What more when there are one or two ASEAN countries that seek China's support on global economic issues. Malaysia is not an exception. While it is comfortable with the US on military security, it prefers China or India to fight for the developing world on economic and environmental issues.

The US global naval strategy also has not changed drastically but has acquired an added dimension in the post-9/11 strategic environment. During the Cold War, the US Pacific Command was tasked with guarding the vital sea lanes in the Indian Ocean, Straits of Malacca, and the South China Sea, up to the Sea of Japan. While these type of naval activities required strong bases in the Philippines, such a role has not diminished with the end of the Cold War. Beside some naval facilities and the visiting forces activities in Singapore and the Philippines, the US is also exploring more places and activities to keep the US navy active in its global mission. Although the strategy has remained the same in many ways, the present naval strategy focuses on humanitarian activities, port calls, and counter-terrorism exercises in addition to other routine or annual exercises. The presence of US ships, naval vessel visits and recent maritime exercises with Vietnam can be regarded as an additional dimension of the naval strategy in order to deal with China. In August 2010 the US destroyer USS John S. McCain was that taking a port call in Vietnam with some 270 sailors. This was followed by the USS Avenger, a mine counter-measure ship doing the same thing. Training between the two navies included areas such as damage control, emergencies and firing control. The aircraft carrier USS George Washington had also made visits despite protests from China in its involvement with naval exercises in the Yellow Sea. The Vietnamese have developed trust and friendship with the US for nearly 15 years after the normalization of the relationship. Vietnamese officials view that the presence of a US ship would provide a necessary balance in defence and security of the region (NST, 2010c). It is in the interest of Vietnam to ensure China is checked in the South China Sea.

After 9/11, the need for interdiction of ships belonging to rogue nations and terrorist groups has intensified the naval and maritime interests of the US and its regional allies. It is also vital for the US Navy to keep its presence in order to influence foreign policy outcomes in East Asia while ensuring allies that it remains a reliable strategic partner. It is also important for the US to camouflage its maritime strategy under a number of alliance states in the name of joint exercises, humanitarian assistance and counter-terrorism exercises. The ultimate goal would be freedom of navigation, market access, and ensuring the US interests and triumph of capitalism and democracy. It is commonly argued that 90 per cent of global trade is reliant on maritime commerce. To separate the strategic interests of US sea power from the commercial dimension, from Mahan's point of view, will be going against its very purpose. Therefore, the US would use all available opportunities and crises, be it maritime commerce, piracy, 
maritime terrorism, disaster relief and a humanitarian mission to forward its presence and power projection. This will be used as a reminder and is a way to check any rising belligerence. Whether Beijing likes it or not, China will be a constant on US militarystrategic observation radar.

In recent years, China has also been behaving more aggressively and assertively. Beijing's protest over the imminent naval exercises involving the US aircraft carrier in the waters of the Korean Peninsula after the recent spate between North and South Korea due to the sinking of the Cheonan warship also tends to challenge the US Pacific Command. Washington is certainly not happy when its dominance in the maritime space is challenged. It is even more since it involves legitimate US military interests. China has become impatient with the US, especially so when the US continues to sell offensive weapons to Taiwan. Therefore, in analysing the US role, the military issue and naval strategy in the South China Sea should not be seen in isolation. The US maritime strategy must be viewed from an overarching perspective straddling from the control of maritime commerce and military vessels from the Indian Ocean up till the Sea of Japan.

Historical defeat in Vietnam and the challenges posed by China in the Korean War cannot be forgotten easily by the US. The US-China military rivalry in space defence is another issue altogether that warrants a separate discussion on animosity and tension. China's shooting of a satellite with a missile and the US response to this in an almost similar fashion within the last two years cannot be easily forgotten. Similarly, the tension in the relationship between the US and China is also caused continuously by extensive cyber warfare activities targeting the US by Chinese citizens. Cyber espionage and attacks on the US critical assets and system has increased in recent decades. In 2008, the US experienced 5,488 known breaches of its computers and system and 54,640 incidents of cyberattacks against its Department of Defence. Besides these activities, US citizens were also arrested for providing system-related information of weapons to Chinese officials (Wortzel, 2009).

Overall, the above incidents and rivalry in the military arena is likely to create more troubles in the future. The US also is increasingly frustrated as China is not being punished. Bilateral relations between the two countries are not at the best level, although leaders' visits tend to mitigate the momentum positively. It could be argued that State of Secretary Hillary Clinton and Defence Secretary Robert Gates have made a point to assert the US military role in defending its national interest by declaring that the South China Sea cannot be regarded as internal waters. The raising of this issue during their visits to the ASEAN region in recent months indicated a direct challenge to what China believes is its security interests in the South China Sea. Since the arrival of Trump, The US position in the South China Sea is further hardened with more freedom of navigation role for the US ships. Many times US ships had been sailing within the 12 nautical miles of China's land reclamation zone in some of the reefs control by the PRC. Statements of Trump administration Defence Secretary and also the State Secretary indicates a more assertive role on the Freedom of Navigation policy in the South China Sea which angers Beijing. 


\section{China's Maritime Strategy in the South China Sea: Old and New Approaches}

The PRC has its own strategy to expand its presence and control with a nine-dash line in the South China Sea.. David Muller's work on China as a maritime power during the height of the Cold War revealed that the PRC's navy in the 1980 s consisted of 80 submarines, 800 fast patrol craft, 30 or so destroyers and frigates built in the 1970s. Most of these cannot be regarded as modern warships. The navy's dependence on army generals "calling the shots" had hampered the progress of its sea power. However, the presence of the Soviet Union's significant naval force in Vietnam had an impact on the continuous development of the PRC's navy during the mid-1970s and 1980s. It was indeed difficult to say if China's navy could effectively fend off the Soviet amphibious assault in the South China Sea (Muller, 1984; Spurr, 1984). However, it was necessary to note that by 1974 , China had already attacked and forced out Vietnam from the Paracels islands. This can be regarded as a major victory for China.

The People's Republic of China (PRC) is a latecomer to the territorial disputes in the South China Sea. China's sovereignty claim to the South China Sea was kept under control with democratic China occupying the Itu Aba island in the Spratlys after the Japanese surrender. Therefore, Taiwan had been the protector of China's interest for many years, ensuring that its historical claim has sufficient basis. Until the 1980s, PRC allowed Vietnam, the Philippines, Malaysia and others to occupy the Spratlys group. With the forceful removal of Vietnam from the Paracels group in 1974, China began to be assertive and focus on developing its naval force so that it can protect its claim based on historical interests in the South China Sea. By March 1988, China attacked Vietnam once again, but this time in the Spratlys. The 1988 attack on Vietnam-occupied islands in the Spratlys was planned correctly. For almost six months prior to the March 1988 attack, the PRC's navy was conducting extensive naval exercises in the South China Sea covering some 57,000 nautical miles. The exercise involved submarine reconnaissance and simulated torpedo attacks around the Spratlys (Simon, 1991).

Since the 1988 skirmish with Vietnam, China began to explore more islands and atolls by increasing its naval presence in the South China Sea. Its naval base in Hainan Island was used as a platform to administer the South China Sea. China does not view the Spratlys and the South China Sea in isolation from a strategic point of view. The PRC's maritime strategy, although stemming from the pressure posed by the other superpowers, is fully aware of the fact that there is a strong link between maritime strategy and its commercial interests. China's naval officers had acknowledged in the late 1980s that China's maritime strategy in the Spratlys must be viewed in the holistic context of its maritime commerce passing through the Persian Gulf, the Indian Ocean, the Straits of Malacca and the South China Sea (Cushing, 1988). China is fully aware of the importance of controlling the sea lanes in the long term. Controlling its stake in the Spratlys and the South China Sea was vital for its long term survival. The idea of the South China Sea as an important survival space which must be recovered from the contested parties has long remained an important dimension of the PRC's naval strategy.

The famous 1995 Mischief Reef located within the Philippine's EEZ became the tilting point in the PRC's maritime strategy. The 1995 Mischief Reef revealed to all claimants that China has a clear maritime strategy in the South China Sea to fortify its 
position militarily. The 1990s witnessed the PRC occupying about eight islands in the Spratlys. Vietnam also fortified its position in the Amboyna Cay following Malaysia's adventurism in the Spratlys after publishing its 1979 EEZ maps which was protested by all the claimants. Generally, it can be easily argued that China did not have a clear maritime strategy and capabilities until the late 1980s. But the activities of other claimants like Vietnam, the Philippines and Malaysia propelled China to strengthen it naval presence in the South China Sea. China's development of its navy the 1980s was a response to Vietnam's hosting of the Soviet forces in the Cam Ranh Bay and Danang. The Soviet naval activities in Vietnamese waters were of major concern during the Cold War. The Mischief Reef incident in 1995 after the Cold War can be regarded as an important event in which China's military role in the South China Sea became apparent and more dominant. Some of the ASEAN nations were also alarmed and started fortifying their naval capability while diplomatically pressing China into signing the ASEAN documents.

China has also been occasionally putting up a ' $U$ ' shape map as justification for its sovereignty to the entire South China Sea. Although other claimants protest this, nothing could be done to slow down the PRC's adventurism in the South China Sea. All the claimants, including China and Taiwan, have established naval outposts and landing strips for their respective air forces. Some have developed their occupied islands as tourist spots for diving and have even built hotel resorts on them. Malaysia is no exception to this. China has issued warnings directed at the other claimants for developing the islands. In 1995, immediately after the Mischief Reef incident, ASEAN and China met to discuss a Code of Conduct in the South China Sea in order to prevent provocative acts in the Spratlys. However, this did not stop China from looking at new atolls to be captured. The tension was high in 2002 when finally ASEAN and China signed the ASEAN Declaration of Conduct in the South China Sea. China also signed the ASEAN Treaty of Amity and Cooperation (TAC) soon after. But this has yet to stop the naval developments in the South China Sea. China did not adhere to this Declaration as its naval visits to the South China Sea had increased by then. In April 2009, PRC's vessels challenged the US Impeccable from conducting scientific surveys in the South China Sea. China's aggressive approach in the South China Sea has influenced Vietnam to conduct a naval exercise with the US, a similarity to its relationship with the Soviet Union during the Cold War. But of course, the number of ships involved was far less and more on a friendly basis. The intensity of Vietnam-US naval cooperation may increase tensions depending on China's future behaviour.

But for China, having control over the SLOCs in the South China Sea, the Straits of Malacca and the Indian Ocean are pivotal to its maritime strategy and longterm interests. China has now replaced Japan as the second-largest economy in the world. It's military too has been developed with better patrol crafts, frigates, destroyers, aircraft carrier and submarines for managing potential threats and addressing more significant challenges that can come from the US and its allies. Its military budget has experienced double-digit growth within the last two decades (Balakrishnan, 2009). Although technologically the PRC's military may be inferior to the US, it has developed significant capabilities in other areas such as in missiles, fighter aircraft, aircraft carriers and warships to deal with perceived threats from the US and its allies. China's military 
training and capabilities for the $21^{\text {st }}$ century are designed for facing more significant challenges beyond the South China Sea.

China's maritime strategy is now expanding to Africa and Latin America in order to provide cover for its growing economic interests and collaborations with countries that may not be liked by the West. This is also in line with the Belt and Road Initiative (BRI). In 2009, China has dispatched its vessels to the Gulf of Eden due to the rise in piracy to protect its commercial ships. We are witnessing more of this type of role increasing in the future. China has acquired an aircraft carrier and almost completed building the second Carrier. It has gained sufficient knowledge on manning such crafts after purchasing second-hand carriers from Australia and Russia. In 1985, China bought an Australian carrier, HMAS Melbourne, which was not developed for naval operation. The ship became scrap in the naval dockyard. However, this may not be the case for the Russian Varyag purchased to be used as a floating casino. In 2005, Janes Defence reported that the Varyag was being refurbished in the naval dockyard in Dalian. There is a possibility that the carrier would be able to accommodate the Sukhoi 27 and 30s. China had also purchased two Kiev-class carriers. The Minsk and Kiev were also purchased in the aftermath of the Cold War (Lim, 2005). Potential for more aircraft carrier cannot be dismissed given China's wealth.

It is believed that the navy has now done extensive study and training for pilots to operate from the carrier platforms. Although these aircraft carriers could not be upgraded and manned the way it was expected, it will not be too long for China to acquire or build such capability. The Varyag could be the first carrier of potent capability if its refurbishment becomes a reality. If China could spend billions of dollars on developing space warfare capabilities, it will not be too long for it to strengthen its sea power. What more when 90 per cent of the global trade is still seaborne in many ways. China has also asked Taiwan to cooperate in the South China Sea as the relationship between the Taipei and Beijing improved significantly with a successful conclusion of the Free Trade Agreement (FTA) in 2010. Although Taiwan has yet to respond positively for many years, it is just the beginning of a new era in which China is exploring ways to strengthen its maritime alliances in the region. The US already had a very low-level naval exercise with China as part of a confidence-building exercise. How this will further develop is something that needs to be seen.

For the time being, the US is unlikely to budge from its position that the South China Sea is also a part of its national interest. China will also continue to strengthen its position in the South China Sea because of its future energy and economic needs. Various scientific expeditions and researches conducted by the PRC has confirmed that the Spratlys is an area of high potential for oil and gas, potentially worth billions of dollars. The more the global energy crisis heightens, the more unlikely it is that China will be accommodative on the issue of its sovereignty and control over the South China Sea. China's economic development has resulted in drastic increases in oil imports and maritime transportation. The security of SLOCs is something vital for China in order to sustain its continuous economic growth.

Seaborne trade was always on the path for more growth since the 1990s. Today, it is in trillions. Professor Ji Guoxing, a Chinese expert on maritime affairs, highlighted that China's seaborne foreign trade capacity was estimated to reach 656 million tons in 2005 from only 383 million tons in 1998. China's number of ships combined with Hong 
Kong will make it the third-largest shipping fleet in the world. Gouxing estimates that China's oil demand is increasing at 4-5 per cent annually. Its annual requirement is 220 million tons, with half of it imported. It is also important to note that almost 60 per cent of China's oil imports pass through the Straits of Malacca and the South China Sea from the Middle East (Ji, 2004). The past trends also reveal that between 1996 and 2000, China's oil imports had grown five-fold reaching 70 million tons. The main reason for this was the 900,000 automobiles purchased annually, and some 8,000 apartments purchased a day by the year 2000, forcing the demand for energy and electricity. The analyst also predicted in December 2001 that China would have to depend on the import of almost half of its oil supply for energy needs by 2010 (Roberts \& Clifford, 2001). The trend of the first decade of the $21^{\text {st }}$ century is even better now in 2019 as China is aiming to be the world number one economy. These economic facts are critical in analyzing on how China will deal with maritime security and SLOCs-related issues, be it in the South China Sea or elsewhere in the world.

Energy needs are forcing China into becoming more assertive and tough on territorial disputes by using its military power. Incidents in 2010 indicate that China is acting in a non-compromising manner in areas of territorial disputes. First, when the Japanese Coast Guard detained a fisherman boat from China colliding with the enforcement boats on September 2010. Beijing pressured Japan to release the captain and 14 crew members as well as the boat. Japan had no choice but to release them seeing the mounting pressure in the Chinese media. The captain of the ship is being held temporarily. China has been firm and is not ready to compromise. Of course, both parties would not like the consequences of a big-scale naval flare-up that can cost each other heavily. The incident occurred near Japan's Kuba Island, which is part of the East China Sea territorial dispute between China and Japan, which involves the ownership of Diaoyu or the Senkaku group of rocks. The area is predicted to have vast reserves of oil and gas. Chinese estimates are placed at nearly 500 cubic of natural gas and more than 20 million barrels of oil, and it is also regarded as an area of almost 20 per cent of China energy reserves (NST, 2010d; NST 2010e). Second, China has also been drilling gas near the Japanese maritime boundary, which the PRC disputes in recent years. Reporting on the issue, Mark Valencia observed that China's naval vessels and guided missiles destroyers are all well-placed near the disputed areas as a deterrent. The Japanese had also noticed China's nuclear submarines in Japanese waters in November 2004. It was reported that for six months in 2006, there were about 25 incursions of Chinese exploration ships into Japanese waters (Valencia, 2006). Chinese fishermen were also fired upon by Indonesian maritime enforcement officers in 2010. The incident sparked tension and the pressure on Indonesia was enormous. Between 2010 and 2019, more incidents of conflict with China in the South China Sea have experienced by Vietnam, Indonesia, Philippines and Malaysia.

The above incidents in recent decades reveal that China could pressure a much stronger navy such as Japan's to behave accordingly in disputed territorial waters although Chinese citizens appear to be at fault. In addition, the oil and gas exploration activities since 2005 tend to explain well that the PRC's navy is ready for war in order to protect its maritime resource interest in disputed areas of a territorial dispute involving her sovereignty. While there is the intention to work on joint exploration in the East China Sea, the PRC will likely do so on its terms. Both Japan and China had 
attempted to discuss these issues in bilateral dialogues, but the problems have not been fully resolved, and Beijing's stand has been one of no compromise in most instances. Perhaps these incidents can be a guide to smaller players in dealing with China in other areas such as the South China Sea. Other claimants too find China's position as threatening within its so-called its nine-dash line.

In addition, there are also new developments that reveal the rise of China's military power and assertiveness on great powers other than Japan or India. In recent months, Beijing has indicated to the US that China does not tolerate the American military exercises near its regional vicinity with South Korea or Japan. While the places of naval exercise involving the US battle carriers may not be near China's EEZ, Beijing still views it as directed at China despite the joint naval exercise involving only South Korea whose aim was to respond to the sinking of Cheonan warship by the North Koreans. US strategist, Ralph Cossa of the CSIS Pacific Forum in Hawaii notes that the PLA commentators have been warning that there can be possible collisions with the PRC's Navy ships if the US-South Korea joint naval exercise materializes. He argues that the location of the naval exercise is far from the Chinese coast in the Yellow Sea and the PRC's claim is not acceptable. When the North Korean shooting of the Cheonan was referred to the United Nations Security Council, China acted as North Korea's "attorney." According to Cossa, of late allies such as South Korea and Japan have been feeling that the US has been more submissive to China's demand of not dispatching its aircraft carrier, George Washington. Cossa views these developments as challenging the very principle of freedom of navigation and US interests (Cossa, 2010). ASEAN countries and the US were also warned by China not to meddle on the issue of the South China Sea during their bilateral summit in Washington on September 2010. In recent years, China has taken advantage of the Code of Conduct on South China Sea forum with ASEAN to establish its interest strongly.

Overall, there is a significant change in China's maritime strategy not only in the South China Sea but in other areas of seas as well. These strategic military realities are also in parallel with the nature of the South China Sea as one maritime area bound by several unresolved territorial disputes. The Spratlys group of islands is the most difficult one to resolve while the rest may involve several bilateral solutions. There is also serious concern over competition for economic resources such as oil and other marine living resources in the disputed maritime area. Nations rely on their military capability in order to defend their interests. China is no exception to this as it believes that it is the latecomer in the territorial disputes in the South China Sea, whereas the others have taken advantage early on their sovereignty.

China also fears that ultimately, the US will have the ability to block the sea lanes adjacent to China and the Straits of Malacca in a real battle scenario in the maritime zone. In order to prevent this from occurring in the future, China needs to have sufficient capability for a show of presence and power projection in the South China Sea, which it regards as its internal waters. Denying the advantage to the enemy is crucial indeed. The US is also very much concerned with the increase in the number of Chinese submarines and their alleged spying activities on US naval exercises in the Asia Pacific. In 2007, the US was caught by surprise that the PRC submarines have been spying the naval exercise involving the battle carrier USS Kitty Hawk far away from East Asia in the Pacific Ocean. The Song Class submarines are small and difficult 
to be detected when it is running on an electric motor (NST, 2007). The production of this type of submarine has been increasing.

Overall, it is China's strategy to deny the US and its ally's sea access and ensure it has sufficient capabilities to deal with the Pacific Fleet and other aircraft carriers from reaching China. The military rise in the number of missiles, aircraft, as well as all range of warships and submarines, will likely deal with such imagined threat effectively. While war is what it wants to avoid, preparation, and defending the dignity of the nation is always in the minds of China's strategic planners. Land reclamations activities of the PRC in the South China Sea are always on the increase. China's maritime militia, coast guard ships and navy are more active in recent years and have intruded the EEZs of other ASEAN claimants. China's aircraft carriers will grow in numbers in the coming decades.

\section{The Prospects for Peace and ASEAN's Dilemma on Maritime Disputes}

China's military build-up and aggressive actions in areas of maritime territorial disputes send negative signals to neighbouring states, including ASEAN. It can be construed that military preparation and building alliances are vital in order to address the emerging China challenge in the South and East China Seas. This development can result in rivalries among the states bordering the maritime space of East Asia, which include ASEAN. For countries which depend heavily on this vital sea lane, the stakes are high. These include the United States, Japan, South Korea and the ASEAN countries in East Asia. China's occasional sounding of joint development in disputed areas is often ambivalent. Therefore, the focus on maritime forces involving the development of a modern navy, air support and other enforcement agencies have been ongoing for quite a while. The 1982 UNCLOS has also complicated the situation by exacerbating the scenario of overlapping maritime boundaries in the South China Sea. Claimants like China regard the sea as internal waters using historical evidence as they perceive it. Vietnam and the Philippines also use history as the basis for their sovereignty.

Some of the pertinent issues in the South China Sea security aside from the overlapping territorial disputes which bear a military dimension include piracy, maritime terrorism, unilateralism in sea lane affairs, threats to shipping, external power interests, geopolitics, military technology and supply-side pressure from arms sellers, new resource discoveries, potential for accidental clashes, the issue of freedom of navigation and other non-traditional security issues including smuggling. The above issues, whether we like or not will have some important bearing on military developments in the South China Sea and the global maritime space in general. The extent which the above issues drive military activities and maritime strategy in general needs further investigation. One of the prime concerns of this study is to track the naval and other maritime forces build-up in line with the above developments in the South China Sea. How much military build-up impacts upon the overall security scenario in the South China Sea will determine the priority of concern.

The analysis above reveals that China's military rise has resulted in more tension and problems for the lesser players. Prospect for conflict resolution is not good given China's expansion and land reclamation activities in the South China Sea. The US has also been embarking on China threat since the mid-1990s and till now under the 
Trump administration. The presence of numerous territorial disputes in East Asia, particularly in the South and East China Seas invites the US as a natural partner to the weaker ASEAN states that fear a belligerent China. Vietnam too has realized the importance of having the US military presence on its shores. The visit of the US warships in these areas is seen as vital for Vietnam's national interest.

The East and Southeast Asian regions have numerous unresolved territorial disputes. The popular ones include the islands like the Spratlys, Paracels, waters offcoast the Natunas, Pratas, Diayou/Senkaku, Tokdo and Kuriles. ASEAN, Taiwan and Japan remain a major challenge for China in its Southern and Eastern seas. Malaysia has one of the most extended coasts because of the inclusion of Sabah and Sarawak in 1963. The introduction of the 200nm-EEZ had placed Malaysia in the limelight since 1979 when it first published a map which included this expanse of maritime space. The dispute on overlapping maritime zones of Malaysia with neighbours such as Indonesia, Brunei, the Philippines, Thailand, Singapore, Vietnam, and China has made it difficult for Malaysia in managing security issues. However, Malaysia has been consistently looking at UNCLOS, joint-ventures and cooperative initiatives in order to safeguard its interests. The use of force for resolving disputes is not what the smaller nations believe in. Malaysia's submission of its sovereignty disputes with respect to Ligitan-Sipadan and Batu Puteh to the International Court of Justice can be seen as good examples. Joint development efforts Malaysia initiated thus far with neighbouring countries like Brunei, Thailand and Vietnam shows that these nations are a responsible player in settling regional maritime disputes.

However, territorial issues are not that simple. The military developments in the region are an ongoing phenomenon that warrants attention and vigilance. Some disputes can be resolved bilaterally, while others need a multilateral solution. There are some disputes which have had some level of success such as those involving MalaysiaIndonesia, Malaysia-Thailand, Malaysia-Singapore and Malaysia-Brunei over areas of overlapping claims. So far negotiations are underway bilaterally to overcome the dispute and sometimes to mitigate the possibility of the problem from escalating into violent conflict. Numerous bilateral technical committees have been ironing out the problematic issues so that regional peace is maintained at all times within ASEAN. All ASEAN members and China are signatories to the Treaty of Amity and Cooperation. Malaysia, for example, has sustained the policy of using law and confidence-building measures to enhance friendship so that issues are worked via peaceful means. In line with this spirit, ASEAN and China has signed the ASEAN's Conduct of Parties in the South China Sea in 2002. But this has yet to progress further, except in preventing a major war. However, China, the Philippines and Vietnam agreed on the jointexplorations initiative for Spratlys in 2005, although that remains to be seen in terms of its implementation. Some regarded the 2005 effort was a failure. While the confidence and security-building measures are underway, tensions are also rising due to the resource potential of overlapping EEZs in the South China Sea.

South Korea has recently protested Japan's effort to conduct explorations near Dokdo island. Similarly, China does not favour Japan's activities near Senkaku. The East China Sea is a potential flashpoint, especially when inter-state relations are tense. China and Vietnam have an issue over exploration activities near the Paracels and the Gulf of Tonkin. Vietnamese protests over China's role in the South China Sea have 
increased recently, although bilateral dialogue between these two states on this matter has also increased. To date, the only major military-related security problem of ASEAN with China is the island disputes in the South China Sea, namely the Spratlys and Paracels. The issue over the Spratlys involves four ASEAN members, while the dispute over the Paracels is only between Vietnam and China. How long peace can last in the South China Sea is an issue that remains to be seen.

History indicates more problems. In 1988, China shot down a Vietnamese boat which resulted in the death of all Vietnamese soldiers on board the vessel. In 1995, China built an octagonal ship landing military structure in Mischief Reef near the Philippine EEZ. China's military activities in the Spratlys have increased ever since although diplomacy and dialogue with ASEAN appear to pacify the reality of the Beijing threat. There were occasions in which shooting took place between Vietnam and China over oil explorations in the overlapping EEZ near the Gulf of Tonkin. Vietnam is perhaps the country which has the worst experience of China's harassment in the overlapping maritime zone. But this too has reduced since 2005 when China, Vietnam and the Philippines signed a Memorandum of Understanding on joint exploration. But between 2009 and 2019, tension with China near the Spratlys increased for both the Philippines and Vietnam. By 2019, more issues of ship harassments were reported. China has consistently blocked efforts of oil explorations by the Philippines and Vietnam. China challenge is ever a growing threat.

Another proposal in the positive direction was the Pan-Tonkin Gulf Cooperation which may reduce tension and spur joint exploration activities. Vietnam and China have also been engaging in bilateral dialogue over border issues. However, there is no concrete recorded success in this area thus far. The desire for oil and other resources will likely make island sovereignty disputes and maritime boundary issues more difficult to be resolved. China needs resources more than the rest of the contestants. China's position concerning its baselines issued in 1996 in the South China Sea cannot be taken seriously under UNCLOS. Indonesia protested this and other ASEAN members as the "U" shape baseline put five ASEAN countries and their oil exploration facilities in dispute with China. China's recent attempt to use similar maps to protest Vietnamese and Malaysian claims for an extended continental shelf in the Spratlys reveals that Beijing is still far from following maritime law. Beijing's effort to work with ASEAN on a Code of Conduct for SCS is also far from bringing any positive result to reduce tension between the claimants.

Illegal attacks on ships using the South China Sea waterways were also suspected to involve Chinese authorities in some past cases. For example, in 1994, Hong Kong blamed Chinese authorities for carrying out almost half of the 100 attacks on ships. But the situation has improved in recent years. With the rise in oil prices, exploratory activities will increase and bound to bring problems to bilateral and intraregional relations. In line with it, the level of arms buildup in East Asia has been constantly on the rise. What more when numerous territorial issues remain unsettled. While negotiations and the CSBM (confidence and security-building measures) activities are on the increase, disputing states have never given up on building up the level of the armaments in the maritime zones. The navies are spending billions of dollars in the Asia Pacific region for beefing up their maritime security capabilities. 
This includes all level of amphibious capabilities for the military. Submarine operations in the South China Sea are on the rise. Similarly the visits of more aircraft carriers.

Thailand's purchase of a helicopter carrier in the late 90s was a case in point. The justification for procurement given by the Thai navy at that time was for search and rescue missions. The naval or the maritime dimension continues to be an important focus among the armed forces in the region, especially in East Asia. Many of the ASEAN states, including Malaysia, are working towards preparing for potential flashpoints. Advance fighter wings, submarines and patrol crafts are increasing in number in the region. Better radars are on the rise for tracking miniatures given the rise in the potential use of the unmanned aerial vehicles (UAVs) in the regional maritime zone. China's military build-up, modernization and changing strategy have become a cause for concern in and outside the region. The costs of war can be devastating. The regional states would definitely want to avoid it. At the same time, national pride, sovereignty, and the show of strength embedded within all manoeuvres encourage military acquisition and competition.

Accidental escalations cannot be ruled out. Similarly, the incidents like the Mischief Reef in 1995, of which ASEAN could do nothing about to remove China from Philippine's doorstep, can recur in the Spratlys. The Philippines and Vietnam are already facing this type of challenges from China as regards to oil explorations in their EEZs. While dialogue continues, the contest for resources and territory cannot be ruled out. Resources are becoming more critical than territorial sovereignty. Oil exploration activities have increased with a lot more joint ventures and concessions given to foreign oil companies. Japan, China and ASEAN countries are all involved in one way or another in search for oil and gas in the disputed zones. The maritime zones of Southeast and Northeast Asia will likely witness more explorations activities and rivalries. The rise in the global oil price can be an important trigger. Cases like Ambalat between Malaysia and Indonesia some years ago are good examples to observe carefully. The unsettled issues in many bilateral cases like Batu Puteh case can drive involved parties to consider beefing up maritime security and military activities.

Malaysia has also realized that many more islands need additional cover. For a country with a sizeable maritime space, the number of patrol vessels is still inadequate. The acquisition of more patrol vessels is necessary to guard against several illegal activities which are on the rise. In this context, ASEAN members would think about spending more to improve naval and maritime enforcement capabilities. Whether Malaysia likes it or not, the military build-up will always remain a concern. There is also a need for equipment for the new Malaysian Maritime Enforcement Agency (MMEA). Although the increase in procurements in the region cannot be regarded as an arms race, the development of China's navy, in the long run, will force several ASEAN countries to respond accordingly. Since Beijing succeeded in developing its aircraft carrier, the response from the region is also not favourable. The naval buildup due to the China-Taiwan tension too can affect ASEAN. Indonesia and the Philippines have neglected defence modernization for quite a while and are also currently planning an upgrade. President Jokowi has developed an Indonesian Maritime Strategy or Fulcrum of vision As the naval capabilities and systems begin to improve, another round of reactive procurements can take place because of this longstanding unresolved dispute with China. 


\section{Conclusion.}

Military issues are here to stay for a long time in the South China Sea. More so with superpower rivalry in maritime affairs. There is always a need to upgrade equipment in line with the revolutions in military affairs (RMA) standards. The market or supply-side pressure emanating from the defence industry in the Western world is another ineluctable thing which can influence procurement or interactive purchases from within the region. Great power is always into selling arms in the tension zone. Military development observations and vigilant will be both on the quantitative and the qualitative dimension of the regional build-up. There is indeed a severe need for ASEAN countries, including Malaysia, to observe the kind of spying activities that are taking place in the South China Sea. Purchases of drones and surveillance aircraft and coastal patrol ships are growing in numbers. Recent years have witnessed the rise of intelligence gathering activities in the maritime zone of East Asia. This will be of concern for Malaysia and others in protecting their national interests. For all ASEAN members, military developments in this zone will be an important concern.

Similarly, tension at the intra-ASEAN level too cannot be ruled out because of the unresolved and contested maritime disputes and oil exploration activities. While cooperation and confidence building can be a preferred mode of engagement, the construction of military structures in the South China Sea cannot be easily halted. The show of naval presence and economic activities in the South China Sea will only increase. So long as the problems of territorial issues remain unsettled, this trend will continue in the coming decades. China is also not serious about concluding the Code of Conduct in the South China Sea. The ASEAN-China dialogue on this is being prolonged for giving Beijing an advantage. This can only make the situation worse for power rivalry between the superpowers.

\section{References}

Balakrishnan, K. S. (2009). China's rising defence expenditure and military build-up: Substantial reasons or exaggeration? In E. Kok \& Joanne (eds.), China in the world: Contemporary issues and perspectives (pp. 17-28). Kuala Lumpur: Institute of China Studies, University of Malaya.

Bateman, S. (2010, August 16). The South China Sea: When the elephants dance. RSIS Commentary.

Bergin, A. (1983, September). Navigating the Montego Bay Convention: Implications for navy and naval convention. Asian Defence Journal.

Cushing, J. (1988, May 5). The dragon's long reach. Far Eastern Economic.

Cossa, R. (2010, August 23). China's expanding coastal waters. PacNet.

Far Eastern Economic Review (1990, April 12). The US ponders other regional alternatives.

Hassan, M. J. (2010, August 9). Calming the waters in the South China Sea. New Straits Times. 
Hayton B. (2014), The South China Sea: The Struggle for Power in Asia, New haven: Yale University Press.

Ji, G. (2004, July 8). US RMSI contravenes UN convention on the law of sea, PacNet 29.

King Jr, N. (2007, August 23). Sea resistance to sea treaty breaks down. The Wall Street Journal.

Lim, R. (2005, August 26-28). China's muddled maritime strategy. The Asian Wall Street Journal.

Muller, D. G. (1984). China as a maritime power. Boulder: Westview Press.

New Straits Times (2007, November 11). China's submarines pops up out of nowhere. News Straits Times.

New Straits Times (2010a, April 9). US: Dispatch of Chinese Submarines to the Spratlys not a threat. New Straits Times.

New Straits Times (2010b, July 31). China criticises the US over island chains. New Straits Times.

New Straits Times (2010c, August 11). US-Vietnam display military ties. New Straits Times.

New Straits Times (2010d, September 13). China pressure Japan to free crew. New Straits Times.

New Straits Times (2010e, September 14). Japan free 14 fishermen. New Straits Times.

Roberts, D., \& Clifford, M. L. (2001, December 24). Hungry for energy. Business Week.

Shie, T. R. (2004, October 15). Ships and terrorists-Thinking beyond port security. PacNet Newsletter.

Simon, S. W. (1991). China and Southeast Asia: Suspicion and hope. Journal of East Asian Affairs, 5(1), Winter/Spring 1991.

Spurr, R. (1984, November 23). Passive Defence. Asia Week.

Talib, Z. (1992, November 25). US stand on Spratlys issue. The Star.

Valencia, M. J. (1995). China and the South China Sea disputes. Adelphi Papers No. 298. London: Institute of International and Strategic Studies.

Valencia, M. J. (2004). The regime of military and intelligence gathering activities in the EEZ: Consensus and disagreement. MIMA Bulletin, 1(1), pp. 21-23.

Valencia, M. J. (2006, September 15). The East China Sea dispute: Ways forward. PacNet 47.

Wortzel, L. (2009, November 2). China's cyber offensive. The Asian Wall Street Journal. 